\title{
PENDIDIKAN LINGKUNGAN HIDUP DI SMP NEGERI 3 KEBUMEN JAWA TENGAH
}

\author{
Fauzi Setyobudi \\ Saliman \\ Jurusan Pendidikan IPS FIS Universitas Negeri Yogyakarta. \\ uzy022@gmail.com, saliman_jamper@gmail.com
}

\begin{abstract}
Abstrak
Program Adiwiyata adalah salah satu program Kementrian Lingkungan Hidup RI dalam rangka mendorong terciptanya pengetahuan dan kesadaran warga sekolah dalam pelestarian lingkungan hidup. Implementasi program Adiwiyata di SMP Negeri 3 Kebumen merupakan tema yang menarik untuk diteliti guna memberikan gambaran yang kongkrit program pendidikan lingkungan hidup di sekolah. Metode penelitian yang dipergunakan adalah penelitian kualitatif. Informan penelitian adalah: kepala sekolah, guru, wakil kepala sekolah bidang sarana prasarana, humas sekolah, karyawan sekolah dan peserta didik. Lokasi penelitian terletak di SMP Negeri 3 Kebumen. Teknik pengumpulan data dilakukan dengan wawancara, dokumentasi dan observasi. Teknik analisis data menggunakan teknik analisis data interaktif. Hasil penelitian menunjukan bahwa pelaksanaan sudah terlaksana sesuai dengan panduan adiwiyata. Hal tersebut ditandai pada komponen kebijakan berwawasan lingkungan, sekolah merubah visi misi sekolah dan pada kebijakan anggaran, sekolah mengalokasikan dari dana Bantuan Operasional Sekolah. Komponen kurikulum berwawasan lingkungan, dilaksanakan dengan mengintegrasikan nilai-nilai peduli lingkungan ke dalam pembelajaran di setiap mata pelajaran. Komponen kegiatan lingkungan bersifat partisipasif dilaksanakan melalui kegiatan aksi lingkungan baik yang diselenggarakan pihak sekolah ataupun dari pihak luar.
\end{abstract}

Kata kunci: pendidikan lingkungan hidup, sekolah adiwiyata 
Fauzi Setyobudi, Saliman|

\begin{abstract}
The Adiwiyata program is one of policy Indonesian Enviroment Ministry to encourage the building of knowledge and awareness of school community in order for enviromental conservation. Implementation of the Adiwiyata school program in Public Junior High School 3of Kebumen was interesting topic describe the implementation of environment education in school. This was a qualitative study using the qualitative research method. The research informants were the Adiwiyata school team, principal, teachers, vice principal in charge of the infrastructure facilities, school's public relations, school's administrative staff members, and students. The research location was in Public Junior High School 3 of Kebumen. The data were collected through interviews, documentation, and observations. The validity was enhanced by source triangulation. The results of the study are as follows: program has been implemented in accordance with the Adiwiyata guideline. Its indicated by the facts that policy component has an enviromental perspective, the school changes visions, missions, budget policy, and school operational assistance funds. Components curriculum with an environmental perspective implemented by integrating enviroment-caring values into learning. The components of enviromental activities that are participatory in nature are implemented through enviromental action activities held by both the school and outside parties.
\end{abstract}

Keyword: environment education, Adiwiyata school, SMP Negeri 3 Kebumen

\title{
Pendahuluan
}

Indonesia merupakan salah satu negara di Asia Tenggara yang memiliki lebih dari 17.000 pulau yang terbentang dari Sabang sampai Merauke. Secara geografis, Indonesia terletak di antara Samudera Hindia dan Samudera Pasifik, diantara benua Asia dan benua Australia. Indonesia juga merupakan wilayah pertemuan tiga lempeng dunia yaitu Indo-Australia, Eurasia, dan lempeng Pasifik sehingga negara kepulauan ini terletak pada rings of fire atau cincin api yang menyebabkan rawan akan potensi bencana alam. Bencana alam yang terjadi di Indonesia sangat beragam, mulai dari bencana geologi, oseonologis sampai 
meteorologis. Bencana adalah peristiwa atau rangkaian peristiwa yang mengancam dan mengganggu kehidupan dan penghidupan masyarakat yang disebabkan, baik oleh faktor alam dan atau faktor nonalam maupun faktor manusia sehingga mengakibatkan timbulnya korban jiwa manusia, kerusakan lingkungan, kerugian harta benda, dan dampak psikologis (Sudrajat \& Satriyo Wibowo, 2016). Bencana yang terjadi di Indonesia, sebagian adalah murni akibat dari gejala alam seperti tsunami, gempa bumi, dan gunung meletus. Sebagaian lagi adalah bencana karena campur tangan manusia, seperti banjir, tanah longsor dan kekeringan. Bencanabencana yang terjadi tersebut akan menyebabkan kerugian material maupun berdampak pada daya dukung alam.

Daya dukung alam diartikan sebagai kemampuan alam untuk mendukung kehidupan manusia. Berkurangnya daya dukung alam akan berakibat pula terhadap kemampuan alam untuk mendukung kehidupan manusia. Oleh karena itu daya dukung alam harus dijaga agar tetap dapat memberikan dukungannya bagi kehidupan manusia. Daya dukung alam perlu dijaga karena daya dukung alam dapat berkurang atau menyusut sejalan dengan berputarnya waktu dan pesatnya perkembangan ilmu pengetahuan dan teknologi serta kemajuan industri. Perkembangan teknologi dan industri yang pesat dewasa ini ternyata membawa dampak bagi kehidupan manusia, baik dampak yang bersifat positif maupun dampak yang bersifat negatif. Dampak yang bersifat positif memang diharapkan oleh manusia dalam rangka meningkatkan kualitas dan kenyamanan hidup. Namun dampak yang bersifat negatif tidak diharapkan karena dapat menurunkan kualitas dan kenyamanan hidup. Manusia bertanggung jawab atas dampak yang terjadi terhadap lingkungan. Hubungan timbal balik manusia dengan alam sangat 
Fauzi Setyobudi, Saliman|

ditentukan oleh kemampuan manusia dan alam sesuai karakternya masing-masing. Keduanya memerlukan hubungan timbal balik secara berkelanjutan. Melalui pengelolaan lingkungan hidup secara bijaksana selain dapat menyelamatkan dan melestarikan lingkungan hidup, juga dapat menjamin kebutuhan dan kemakmuran umat manusia itu sendiri. Oleh karena itu, keseimbangan dalam lingkungan kehidupan manusia dan lingkungan alam dapat terganggu oleh manusia itu sendiri.

Salah satu ulah manusia yang menjadi perbincangan hangat dan mencoreng upaya pelestarian lingkungan adalah pembakaran lahan gambut untuk dijadikan lahan Kelapa Sawit. Daerah Sumatera marak terjadi kebakaran hutan akibat pembukaan hutan untuk perkebunan Kelapa Sawit. Banyak yang mengecam aksi tersebut dikarenakan dampak yang ditimbulkan sangat besar. Asap pembakaran hutan berdampak pada diliburkan aktivitas sekolah, aktivitas ekonomi terganggu, bahkan sampai ke negara Singapura dan Malaysia (Kompas, 28 Agustus 2016). Kurangnya kesadaran manusia akan pentingnya lingkungan membuat kelestarian alam Indonesia terganggu. Menurut Badan Pusat Statistik tentang Statistik Lingkungan Hidup Indonesia, menyatakan taksiran luas kebakaran hutan tahun 2014 yang mencapai 32 ribu hektar melonjak dari tahun sebelumnya yang kurang dari 4 ribu hektar saja. Pulau Sumatera adalah pulau dengan kebakaran hutan terluas di Indonesia sepanjang tahun 2014 yang dampaknya dirasakan oleh negara tetangga seperti Malaysia dan Singapura.

Kondisi krisis lingkungan sendiri sebenarnya muncul karena kelalaian manusia itu sendiri. Penduduk sebagai komponen pertama dari ekologi manusia, jumlahnya semakin banyak sehingga semakin banyak pula kekayaan alam yang harus 
diambil untuk mencukupi kehidupannya. Kegiatan manusia dengan mengeksploitasi sumber daya yang disediakan lingkungan untuk menjadi bekal akan kebutuhan manusia mungkin masih dianggap suatu kewajaran demi menjaga kelangsungan hidup. Namun tindakan tersebut dinilai salah apabila kebutuhannya tidak pernah tercukupi dan memperlakukan alam berdasarkan keinginan sendiri. Hal ini tentunya akan mengganggu keseimbangan alam.

Seperti yang diketahui bahwa lingkungan bagi manusia merupakan unsur yang sangat penting dalam menjunjung kehidupan. Lingkungan tidak hanya berperan sebagai tempat tinggal manusia, tapi juga mendukung kehidupan manusia. Segala kebutuhan manusia sudah tersedia di alam untuk dimanfaatkan dalam upaya memenuhi kebutuhannya. Dengan adanya interaksi ini maka segala aktivitas manusia akan mempengaruhi lingkungan. Sikap dan perilaku manusia akan menentukan baik dan buruknya kondisi suatu lingkungan.

Berdasarkan interaksi antara manusia dengan alam dan bencana alam yang menyebabkan perubahan pada alam, maka perlu adanya pengelolaan dan pemeliharaan lingkungan dari beberapa pihak. Siti Nurbaya menyatakan bahwa hanya 10\% perusahaan yang mengalirkan dana CSR untuk kepentingan lingkungan (Tribunnews, 2 Juni 2017). Kegiatan pelestarian lingkungan dapat dilakukan melalui pendidikan lingkungan. Pengetahuan akan kondisi lingkungan alam Indonesia perlu diketahui oleh seluruh masyarakat Indonesia terutama para siswa di lingkungan Sekolah.

Salah satu upaya yang dilakukan pemerintah dalam rangka pemeliharaan lingkungan adalah melalui pendidikan. Untuk mendukung perlindungan dan pemeliharaan lingkungan 
Fauzi Setyobudi, Saliman|

hidup di sekolah, maka Kementerian Lingkungan Hidup RI bekerjasama dengan Kementerian Pendidikan dan Kebudayaan RI meluncurkan program sekolah Adiwiyata. Program sekolah Adiwiyata bertujuan untuk mewujudkan warga sekolah yang bertanggung jawab dalam mendukung upaya perlindungan dan pemeliharaan lingkungan melalui tata kelola sekolah yang baik dalam rangka pembangunan berkelanjutan. Sementara manfaat program Adiwiyata bagi siswa adalah menumbuhkan kepedulian terhadap lingkungan dan memahami betapa pentingnya memelihara lingkungan yang baik. Niat untuk meningkatkan kesadaran siswa melalui program sekolah Adiwiyata dirasa kurang efektif. Sekolah dengan fasilitas lengkap dan sudah dilayani penuh oleh sekolah, siswanya malas untuk melakukan kegiatan bersih-bersih sekolah. Berbeda dengan sekolah yang berada di pinggiran, siswanya ramai untuk menyapu dan membersihkan lingkungan sekolah (Banjarmasin Post, 6 Juni 2017).

Salah satu SMP di Kabupaten Kebumen yang mempunyai fasilitas lengkap dan menerapkan program Adiwiyata adalah SMP Negeri 3 Kebumen. Berangkat dari keinginan untuk membentuk dan meningkatkan sikap peduli lingkungan terhadap masyarakat. Sekolah menyadari perannya untuk memberi pengetahuan dan mengajarkan pada siswa ilmu tentang lingkungan hidup dan pengelolaannya. Dalam upaya meningkatkan kepedulian masyarakat terhadap masalah kependudukan dan lingkungan hidup, pendidikan formal (sekolah) diharapkan dapat meningkatkan peranannya dalam membina para peserta didik. Dalam konteks tersebut, Masruri (2002: 132) menyatakan bahwa pendidikan sangatlah penting, untuk membina kepedulian lingkungan hidup. Akan lebih baik apabila dilaksanakan sejak 
dini, sehingga generasi muda memiliki konsep pengetahuan, kesadaran, wawasan, sikap dan perilaku yang relevan dengan tujuan peningkatan kualitas penduduk dan pelestarian lingkungan hidup.

Dalam mewujudkan sekolah yang berwawasan lingkungan, SMP Negeri 3 Kebumen mempunyai visi Membangun Generasi Global, Berjati Diri Indonesia, dan Berwawasan Lingkungan. SMP Negeri 3 Kebumen serius dalam mempersiapkan sekolah Adiwiyata, tidak hanya dari visi dan misi sekolah tapi dari beberapa aksi yang dijalankan untuk menunjang pembelajaran berwawasan lingkungan. Sejak tahun 2013, SMP Negeri 3 Kebumen berhasil merealisasikan beberapa aksi. Dimulai dari merubah lingkungan yang asri dan nyaman untuk pembelajaran dengan menanam pepohonan yang rindang di halaman sekolah. Selain itu sekolah juga merancang gazebo untuk belajar, pembanguan biopori, pemilihan kader lingkungan dan masih banyak lainnya. SMP Negeri 3 Kebumen juga dianugerahi Sekolah Adiwiyata Nasional pada tahun 2015.

Dalam mempersiapkan pelaksanaan kurikulum berbasis lingkungan, sekolah juga menyisipkan mata pelajaran mengenai pendidikan lingkungan hidup (PLH). Tujuan dari mata pelajaran pendidikan lingkungan hidup adalah agar peserta didik dapat memperoleh pengalaman belajar mengenai perlindungan dan pengelolaan lingkungan. Tujuan tersebut tidak akan terlaksana dengan baik, jika tidak didukung oleh tenaga pendidik yang kompeten dalam bidang perlindungan dan pengelolaan lingkungan. Tenaga pendidik dalam hal pelestarian lingkungan di kabupaten Kebumen masih kurang. Menurut Dinas Pendidikan Kabupaten Kebumen, pemilihan guru sebagai pembina Adiwiyata hanya didasarkan pada kemampuan pribadi guru tersebut. 
Fauzi Setyobudi, Saliman|

Ditambah dengan tidak adanya penataran tentang pelestarian lingkungan hidup yang dilakukan oleh Dinas Pendidikan. Hal ini yang menyulitkan sekolah- sekolah di kabupaten Kebumen untuk melaksanakan pembelajaran Adiwiyata, tak terkecuali di SMP Negeri 3 Kebumen.

Tenaga pendidik dalam mata pelajaran Pendidikan Lingkungan Hidup di SMP Negeri 3 Kebumen masih kurang. Dalam pembelajaran Pendidikan Lingkungan Hidup di SMP Negeri 3 Kebumen hanya ada satu guru untuk tujuh kelas. Hal ini kurang efektif dalam penyampaian tujuan dari program Adiwiyata. Perlu adanya peningkatan kualitas dan kuantitas tenaga pendidik untuk bidang perlindungan dan pengelolaan lingkungan. Setelah sekolah mempersiapkan tenaga, sarana dan prasarana dan kurikulum pendukung program Adiwiyata, sekolah juga harus merancang kegiatan partisipatif yang melibatkan siswa. Hal ini agar siswa tidak hanya diberikan materi tapi juga bisa merasakan langsung perlindungan dan pengelolahan lingkungan hidup. Jadi siswa tidak hanya mengikuti pembelajaran atau seminar tentang lingkungan hidup tapi harus dilibatkan langsung dalam usaha perlindungan dan pengelolaan lingkungan hidup.

Pelaksanaan program Adiwiyata di SMP Negeri 3 Kebumen selama 3 tahun menunjukan kenyataan dimana program tidak berjalan tidak semestinya. Hal ini menyebabkan munculnya pertanyaan-pertanyaan bagaimana sebenarnya implementasi Program Adiwiyata di Negeri 3 Kebumen. Penelitian ini dilakukan untuk mendapatkan data dan informasi yang mendalam tentang implementasi program Adiwiyata di SMP Negeri 3 Kebumen. 


\section{Metode Penelitian}

Jenis penelitian yang digunakan dalam penelitian ini adalah menggunakan metode studi eksploratif dengan pendekatan kualitatif. Studi eksploratif adalah penelitian yang berusaha menggali sebab-sebab atau hal-hal awal yang mempengaruhi terjadinya sesuatu serta menggali pengetahuan baru untuk mengetahui suatu permasalahan. Penggunaan pendekatan kualitatif dalam penelitian didasarkan pada alasan kepentingan untuk menggali dan memahami program Adiwiyata di SMP Negeri 3 Kebumen. Hal ini karena pendekatan kualitatif adalah meneliti permasalahan yang belum jelas, kompleks dan dinamis sehhingga tidak mungkin menggunakan metode kuantitatif.

Lokasi yang dipilih dalam pelaksanaan penelitian adalah SMP Negeri 3 Kebumen beralamat di Jalan S. Parman No 3 Bumirejo, Kecamatan Kebumen, Kabupaten Kebumen. Penelitian dilaksanakan selama enam bulan pada bulan Juli 2017-Januari 2018. Subjek penelitian terdiri dari ketua tim adiwiyata, kepala sekolah, wakil kepala sekolah, guru, karyawan, dan peserta didik.

Metode pengumpulan data yang digunakan dalam penelitian ini adalah observasi nonparticipant yaitu tidak terlibat langsung dan hanya sebagai pengamat independen. Teknik lainnya yaitu wawancara yang dilakukan dengan mengajukan pertanyaan secara bebas namun masih tetap berada pada pedoman wawancara yang sudah dibuat (Suharisimi, 2013: 199). Pertanyaan akan berkembang pada saat melakukan wawancara. Metode pengumpulan data berikutnya adalah dokumentasi yang berisi data dan dokumen program adiwiyata di lokasi penelitian. instrument yang digunakan dalam penelitian adalah pedoman observasi, pedoman wawancara, alat tulis, alat perekam, kamera, 
Fauzi Setyobudi, Saliman|

dan beberapa data- data atau dokumen-dokumen yang ada di SMP Negeri 3 Kebumen.

Teknik analisis data yang dipergunakan yaitu teknik analisis data interaktif model Miles \& Hubernan dengan langkah kegiatan yaitu data reduction (reduksi data), mereduksi data berarti merangkum, memilih hal-hal yang pokok, memfokuskan pada hal yang penting; data display (penyajian data), penyajian data dalam penelitian kualitatif berbentuk uraian singkat, bagan, hubungan antar kategori, flowchart dan sejenisnya; conclusion / verifikasi, penarikan kesimpulan.

\section{Hasil Penelitian dan Pembahasan}

\section{Kebijakan Pendidikan Berwawasan Lingkungan}

Program sekolah Adiwiyata dilaksanakan karena adanya tanggung jawab besar dari sekolah untuk melakukan penyadaran terhadap siswa. Latar belakang pelaksanaan Adiwiyata sebagaimana yang dituturkan oleh S.N. sebagai penanggung jawab Adiwiyata di SMP Negeri 3 Kebumen adalah keprihatinan pendidik terhadap kepedulian lingkungan yang masih rendah di masyarakat. Tanggung jawab moral sekolah sebagai lokomotif perubahan adalah memberikan penyadaran dan pemahaman pentingnya lingkungan hidup bagi kelangsungan hidup manusia.

... karena masalah lingkungan di masyarakat kita menjadi sorotan banyak pihak. Banyak sekali longsor, kebakaran hutan, banjir, penebangan hutan. Nah kita mau mendidik anak-anak dari sekolah melalui sekolah Adiwiyata. Jadi diaharapkan anak- anak ini kalau sudah besar bisa menerapkan ilmunya tentang pentingnya lingkungan alam. Gagasan itu berasal dari kepala sekolah dan seluruh komponen sekolah. Kemudian sekolah mengajukan ke dinas, terus prosesproses. Kebetulan mendapatkan dukungan dari dinas, kami melaksanakan kegiatannya dan jadi adiwiyata sampai sekarang ini (Wawancara dengan SN, 14 September 2017). 
Hubungan antara manusia dengan lingkungan adalah sirkuler. Segala tingkah laku dari manusia akan mempengaruhi akan merubah lingkungan. Perubahan lingkungan pada gilirannya akan mempengaruhi kehidupan manusia sehingga perlu tindakan nyata untuk melakukan upaya penyadaran melalui pendidikan (Sumarwoto, 2013 : 51). SMP Negeri 3 Kebumen melaksanakan sekolah Adiwiyata karena ada tanggung jawab besar sekolah untuk melakukan penyadaran terhadap peserta didik agar cinta terhadap lingkungan. Hubungan manusia dengan alam yang bersifat sirkular membuat peranan manusia sangat penting bagi kelestarian lingkungan. Melihat banyaknya pencemaran lingkungan yang terjadi, SMP Negeri 3 Kebumen mempunyai tanggung jawab untuk menyelesaikan permasalahan itu melalui pendidikan. Layanan pendidikan penyadaran terhadap lingkungan hidup dilaksanakan oleh sekolah secara integratif dengan fokus penguatan karakter kepedulian terhadap lingkungan.

Salah satu tugas sekolah memberikan pembelajaran, layanan pendidikan yang memadai. Oleh karena itu SMP Negeri 3 Kebumen berusaha memberikan layanan pendidikan yang baik, aktual, sesuai dengan perkembangan zaman. Salah satunya adalah memberikan pembelajaran dan Adiwiyata ini memberikan penyadaran pembelajaran secara integratif untuk menanamkan nilai karakter peduli lingkungan. (Wawancara dengan M, tanggal 15 September 2017).

\section{Kurikulum Berbasis Lingkungan}

Mata pelajaran yang diintegrasikan dengan adiwiyata memiliki tujuan masing-masing. Kompetensi inti dalam pelajaran Ilmu Pengetahuan Sosial adalah menghargai dan menghayati perilaku jujur, disiplin, tanggung jawab, peduli (toleransi, gotong royong), santun, percaya diri, dalam berinteraksi secara efektif dengan lingkungan sosial dan alam dalam jangkaun pergaulan dan keberadaannya. Dari Kompetensi Inti diatas bisa dikatakan 
Fauzi Setyobudi, Saliman|

bahwa nantinya peserta didik mempunyai kepedulian terhadap lingkungan alam dan berinteraksi dengan alam secara arif. Hal tersebut sesuai dengan isi dari visi sekolah yaitu mencetak generasi global, berjati diri Indonesia dan berwawasan lingkungan.

Adiwiyata ini disisipkan di setiap mata pelajaran. Di dalam silabus dan RPP juga kita sisipkan. Setiap mata pelajaran terintegrasi dengan wawasan lingkungan. Adiwiyata hanya sebatas ekstrakulikuler dan itu juga digabung dengan ekstrakulikuler kewirausahaan (Wawancara dengan SN, 14 September 2017).

Guru sebagai pendidik sudah mengembangkan indikator pembelajaran lingkungan hidup. SMP Negeri 3 Kebumen juga mempunyai tujuan untuk mencetak lulusan yang memahami nilai-nilai pelestarian lingkungan. Kurikulum SMP Negeri 3 Kebumen menyatakan bahwa standar kompetensi lulusan adalah mempunyai dimensi sikap sehat jasmani dan rohani sesuai dengan perkembangan anak di lingkungan keluarga, sekolah, masyarakat dan lingkungan alam sekitar, bangsa, negara, dan kawasan regional. Kurikulum Berbasis Lingkungan adalah kurikulum yang memuat tentang materi pengelolaan dan perlindungan lingkungan hidup dalam upaya memberikan pemahaman tentang pentingnya lingkungan. Ahmad Fajarisma (2014: 167) bahwa kurikulum berbasis lingkungan secara sederhana dapat diimplementasikan dengan cara penyampaian materi lingkungan hidup melalui kurikulum yang beragam variasi untuk memberikan pemahaman tentang lingkungan hidup yang dikaitkan dalam kehidupan sehari-hari. Kurikulum tersebut disusun dalam rangka menyadarkan peserta didik dan masyarakat akan pentingnya kelestarian lingkungan hidup melalui pendidikan. 
Materi mengenai wawasan lingkungan hidup harus diintegrasikan dalam pembelajaran. Guru harus mampu mengembangkan isu atau permasalahan mengenai lingkungan hidup ke dalam materi pembelajaran, sehingga peserta didik mampu menyelesaikan masalah di kehidupan sehari hari. Sesuai dengan observasi yang dilakukan oleh peneliti bahwa guru di SMP Negeri 3 Kebumen sudah menggunakan permasalahan lingkungan sebagai bahan diskusi kelompok. Pada saat mata pelajaran IPS dengan tema dinamika kependudukan dan pembangunan nasional, yang menjadi bahan diskusi adalah masalah lingkungan apa yang diakibatkan pertumbuhan penduduk dan mencarilah solusinya. Kemudian di dalam mata pelajaran bahasa Inggris, guru juga menyisipkan materi lingkungan. Hal ini sesuai dengan RPP yang digunakan oleh guru dengan menggunakan materi lingkungan. Guru memberikan contoh struktur teks yang berhubungan dengan lingkungan sekitar, memilih topik yang berhubungan dengan lingkungan sekitar. Di dalam bacaan mengenai ulasan teks, guru memberikan bacaan mengenai pencemaran lingkungan. Kemudian guru memberikan pertanyaan mengenai judul, paragraf pendahuluan, paragraf yang mengandung unsur penolakan dan mendiskusikan ciri bahasa teks ulasan.

Guru SMP Negeri 3 Kebumen sudah mampu mengintegrasikan nilai-nilai lingkungan dalam materi pembelajaran. Banyak sedikitnya teori pendidikan lingkungan hidup tergantung keterkaitan antara PLH dengan materi. Tidak semua pokok bahasan yang ada dalam bidang studi atau mata pelajaran tersebut dapat menyerap materi PLH, tetapi terbatas pada pokok bahasan PLH yang mempunyai hubungan erat dengan bahasan mata pelajaran bersangkutan. Komponen metode 
Fauzi Setyobudi, Saliman|

berkaitan dengan strategi yang harus dilakukan dalam rangka pencapaian tujuan. Metode yang tepat adalah metode yang sesuai dengan materi dan tujuan kurikulum yang akan dicapai dalam setiap pokok bahasan. Guru hendaknya tidak hanya menerapkan satu metode saja, tetapi guru dapat menerapkan berbagai metode agar proses pembelajaran berlangsung dengan menyenang-kan dan mencapai sasaran yang direncanakan.

Di dalam pembelajaran IPS di SMP Negeri 3 Kebumen yang sudah diintegrasikan dengan Adiwiyata, guru menggunakan metode ceramah tapi juga diselingi dengan metode problem based learning. Hal ini sebagaimana sudah diterangkan diatas bahwa guru memberikan masalah apa yang akan ditimbulkan dari adanya keadaan peduduk saat ini di Indonesia. Evaluasi pembelajaran ditujukan untuk mengetahui apakah tujuan kurikulum telah tercapai atau belum. Evaluasi ditujukan untuk menilai pencapaian tujuan-tujuan yang telah ditentukan serta menilai pencapaian tujuan-tujuan yang telah ditentukan serta menilai proses pelaksanaan mengajar secara keseluruhan.

\section{Kegiatan Lingkungan Bersifat Partisipatif}

Kegiatan lingkungan bersifat partisipasif adalah kegiatan yang melibatkan warga sekolah dan masyarakat di sekitarnya dalam melakukan berbagai kegiatan yang memberikan manfaat baik bagi warga sekolah, masyarakat maupun lingkungannya dalam rangka kegiatan pengelolaan lingkungan hidup. Pelaksanaan kegiatan lingkungan bersifat partisipasif di sekolah diintegrasikan dalam kegiatan pembiasaan dan ekstrakulikuler.

Kegiatan lingkungan bersifat partisipasif dilaksanakan sesuai dengan standar sekolah Adiwiyata yang telah ditentukan oleh Kementrian Lingkungan Hidup dan Kementrian Pendidikan. Dalam buku Panduan Adiwiyata (2011 :15-18), standar kegiatan 
yang pertama adalah memelihara dan merawat gedung lingkungan sekolah oleh warga sekolah. Bentuk kegiatan yang dilaksanakan di SMP Negeri 3 Kebumen adalah melalui piket bersama dan ada kegiatan rutin setiap hari Jumat yang dinamakan Jumat Bersih. Kemudian standar yang kedua adalah memanfaatkan lahan dan fasilitas sesuai dengan kaidah-kaidah lingkungan hidup melalui pembuatan kolam, pembuatan taman dan pengadaan alat pengkomposan. Kriteria yang ketiga adalah adanya kreatifitas dan inovasi warga sekolah dalam upaya perlindungan dan pengelolaan lingkungan hidup melalui: pembuatan pupuk kompos dan publikasi kerajinan siswa.

Penyelenggaraan aksi lingkungan tidak selalu dilakukan oleh sekolah itu sendiri, namun sekolah juga dapat mengikuti aksi lingkungan yang diselenggarakan oleh instansi luar. Sebagaimana dijelaskan dalam buku Panduan Adiwiyata (2011: 24) bahwa salah satu standar kegiatan lingkungan bersifat partisipasif adalah dengan mengikuti kegiatan aksi lingkungan yang diselenggarakan oleh pihak luar. SMP Negeri 3 Kebumen memiliki kerjasama dengan instansi lain, antara lain:

a. Pemda Kebumen, dalam hal penanaman pohon di lingkungan alun-alun Kebumen

b. Dinas Lingkungan Hidup, dalam hal pemberian seminar tentang pelestarian lingkungan hidup dan juga bantuan sarana ramah lingkungan

c. SD, SMP dan MTs di kabupaten Kebumen, dalam hal pengimbasan terhadap sekolah agar bisa menjadi sekolah Adiwiyata.

Peran Humas sangat penting dalam hal pelaksanaan kegiatan yang bekerjasama dengan instansi lain. Hal ini dikarenakan Humas memiliki tugas untuk menjembatani pihak 
Fauzi Setyobudi, Saliman|

sekolah dengan pihak luar. Dengan adanya dukungan dari berbagai pihak, sekolah dapat menjalin kerjasama yang saling menguntungkan. Hal tersebut sebagaimana diungkapkan oleh Suryosubroto (1998: 1) bahwa hubungan masyarakat dilakukan dengan tujuan memperoleh keuntungan dan kemudahan bagi kedua belah pihak.

\section{Pengelolaan Sarana Ramah Lingkungan}

SMP Negeri 3 Kebumen dalam rangka mendukung program Adiwiyata telah menyediakan sarana ramah lingkungan. Pengadaan sarana ramah lingkungan di sekolah dilakukan dengan cara pembelian langsung dan hibah dari beberapa instansi yang telah menjalin kerjasama dalam program Adiwiyata. Sarana sekolah baik melalui pembelian pribadi ataupun hibah, harus disesuikan dengan ramah lingkungan. Adapun sarana ramah lingkungan dari pembelian dan hibah tersebut antara lain seperti bak sampah, gerobak sampah, pengadaan alat pengkomposan, tempat sampah dan kolam. Sumber dana dari pengadaan barang-barang tersebut sudah dialokasikan di anggaran belanja sekolah. Alokasi dana tersebut juga digunakan untuk mengelola sarana dan prasarana ramah lingkungan di sekolah.

Semua peralatan pengkomposan, biopori, masih berjalan sebagaimana mestinya. Karena saat ini belum kondusif jadi belum berjalan. Tapi nanti akan dijalankan di ekstrakulikuler. Kita mempunyai tempah sampah yang memisahkan sampah. Kemudian kita punya alat kompos di belakang sana. Kemudian ada taman dan kolam, yah meskipun kecil (Wawancara dengan SN, tanggal 16 September 2017).

Sarana ramah lingkungan yang berasal dari pembelian maupun hibah dari instansi dicatat dalam bentuk kartu inventaris ruangan. Menurut Suryosubroto (2004: 116) dalam 
pengurusan dan pencatatan barang disediakan instrumen administrasi berupa: (a) buku inventaris, (b) buku pembelian, (c) buku penghapusan dan (d) kartu barang. SMP Negeri 3 Kebumen menggunakan kartu inventaris barang berdasarkan ruangan. Hal ini menyulitkan untuk mengelompokkan sarana Adiwiyata dan bukan. Kegiatan inventaris dilakukan pada awal tahun dan dilakukan oleh penanggung jawab sarana dan prasarana. Di SMP Negeri 3 Kebumen kegiatan pencatatan dilakukan setiap bulannya. Hal ini akan mempermudah dalam hal administrasi barang keluar dan barang masuk. Dan meminimalisir terjadinya kesalahan dalam pencatatan. Inventarisasi dilakukan dalam rangka pencatatan dan pengawasan terhadap barang milik negara maupun swasta. Keterlambatan dalam inventarisasi barang menunjukan adanya masalah dalam administrasi sarana dan prasarana. Hal tersebut dapat menghambat pengelolaan sarana ramah lingkungan pada saat perencanaan kebutuhan.

Pemanfaatan sarana ramah lingkungan di sekolah adalah penggunaan tempat sampah dan alat kompos sebagai sarana pembelajaran peserta didik. Bentuk sarana pembelajaran tersebut adalah dengan pembuatan pupuk kompos dan pembuatan kerajinan dari bahan daur ulang di ekstrakulikuler Adiwiyata dan Kewirausahaan. Pemanfaatan alat pengkomposan dilakukan pada kegiatan ekstrakulikuler. Hal ini agar tidak mengganggu pembelajaran siswa dan penggunaan alat pengkomposan. Selain pemanfaatan alat pengkomposan, sekolah juga melakukan penghematan dalam penggunaan air, listrik dan ATK. Dalam penerapannya, sekolah memanfaatkan energi alami dalam hal penerangan dan mengurangi penggunaan AC. Dapat dikatakan di SMP Negeri 3 Kebumen sudah mengindikasikan penghematan penggunaan listrik, air dan Alat Tulis Kantor (ATK). 
Fauzi Setyobudi, Saliman|

Kegiatan pemeliharaan sarana dan prasarana dilakukan oleh komando dari Wakasek bidang Sarana Prasarana. Pemeliharaan sarana dan prasarana ramah lingkungan berfokus pada perawatan dan rehabilitasi kerusakan. Dalam hal perawatan, SMP Negeri 3 Kebumen sudah mempunyai tenaga tersendiri dan dibantu oleh siswa. Pemeliharaan terhadap sarana ramah lingkungan dilakukan secara berkala sesuai dengan petunjuk penggunaan. Pemeliharaan tersebut dilakukan sendiri oleh penanggung jawab atau memanggil tukan servis / ahli dalam pemeliharaan barang tersebut. Pemeliharaan dalam hal perbaikan harus dilihat seberapa kondisi dari sarana tersebut. Sarana dan prasarana yang kondisinya sudah tidak bisa untuk diperbaiki, maka sudah saatnya sekolah untuk melakukan penghapusan terhadap barang tersebut. Ibrahim Bafadal (2004: 63) mengemukakan bahwa penghapusan perlengkapan di sekolah dilakukan dengan beberapa kegiatan yaitu:

a. Mengelompokan perlengkapan yang akan dihapus

b. Menginventarisasi perlengkapan yang akan dihapus

c. Mengajukan usulan penghapusan barang dan panitia penghapusan

d. Panitia penghapusan mengecek kembali barang yang rusak dengan membuat berita acara pemeriksaan

e. Panitia mengusulkan penghapusan barang-barang yang terdaftar dalam berita acara pemeriksaan, dan

f. Begitu surat penghapusan datang, bisa segera dilakukan penghapusan terhadap barang-barang tersebut. 


\section{SIMPULAN}

Implementasi program Adiwiyata di SMP Negeri 3 Kebumen sudah sesuai dengan buku Panduan Adiwiyata. Hal tersebut ditandai pada komponen kebijakan berwawasan lingkungan, sekolah merubah visi misi sekolah dan pada kebijakan anggaran, sekolah mengalokasikan dari dana bantuan operasional sekolah. Komponen kurikulum berwawasan lingkungan, dilaksanakan dengan mengintegrasikan nilai-nilai peduli lingkungan ke dalam pembelajaran di setiap mata pelajaran. Komponen kegiatan lingkungan bersifat partisipasif dilaksanakan melalui kegiatan aksi lingkungan baik yang diselenggarakan pihak sekolah ataupun dari pihak luar. Pengelolaan sarana ramah lingkungan melalui rumah kompos yang disediakan sekolah.

Hal perlu mendapat perhatian dari seluruh elemen sekolah adalah kurangnya partisipasi aktif dari warga sekolah terutama pada aspek dukungan moral dan finansial. Guru dan tim adiwiyata seolah-oleh bekerja sendirian, sehingga perlu adanya kesadaran bahwa pendidikan melibatkan seluruh komponen sekolah baik guru, karyawan, siswa, dan juga masyarakat sekitar sekolah.

\section{DAFTAR PUSTAKA}

Adam, A., \& Fajarisma, B., (2014). Analisis Implementasi Kebijakan Kurikulum Berbasis Lingkungan Hidup Pada Program Adiwiyata Mandiri SDN Dinoyo Malang, Jurnal Kebijakan dan Pengembangan Pendidikan, 2, (2), 166-173.

Arianto, I., (1988). Pendidikan Kependudukan dan Lingkungan Hidup untuk IKIP dan FKIP. Jakarta: Dirjen Pendidikan Tinggi.

Ibrahim Bafadal. (2004). Menejemen perlengkapan sekolah: teori dan aplikasinya. Jakarta: Bhumi Aksara. 
Fauzi Setyobudi, Saliman|

Masruri, MS. (2002). Pendidikan lingkungan hidup. Yogyakarta: Yogyakarta University Press.

Sudrajat \& Satriyo Wibowo, 2016. (2016). Pemahaman menejemen bencana alam pada siswa sekolah menengah pertama, Jipsindo, 3(2), 168-189. Tersedia pada https://journal.uny.ac.id/index.php/jipsindo/article/view/1 $\underline{1697}$

Suryosubroto, (1998). Humas dalam dunia pendidikan. Yogyakarta: Mitragama Widya. 